\title{
Analisis Resiko Keselamatan Konstruksi Pada Proyek Pembangunan Gedung Asrama Haji Padang Pariaman
}

\author{
Utami Dewi Arman ${ }^{1}$, Afrilda Sari ${ }^{2}$, Rita Nasmirayanti ${ }^{3}$ \\ Fakultas Teknik Jurusan Teknik Sipil, Universitas Putra Indonesia "YPTK" "1,2,3 \\ Email: udewi2679@gmail.com ${ }^{1}$, afrildasari@yahoo.com², thaten94@gmail.com
}

DOI: http://dx.doi.org/10.31869/rtj.v4i1.2290

\begin{abstract}
Abstrak: Dalam mengurangidan mencegahpotensi kecelakaan kerja konstruksimaka perlu dilakukan identifikasi, penilaian dan analisis resiko keselamatan konstruksi sebagai pertimbangan dalam tahap pra-konstruksi implementasi SMKK yang dilaksanakan oleh Kontraktor.Penelitian ini bertujuan untuk mengidentifikasi implementasi SMKK dan menganalisis resiko-resiko keselamatan konstruksi pada Pembangunan Gedung Asrama Haji Padang Pariaman. Identifikasi variabel resiko keselamatan konstruksi diperoleh dari penelitian terdahulu, wawancara dan menyebarkan kuisioner kepada 30 (tiga puluh) responden dari kontraktor yang ada di Kabupaten Padang Pariaman. Penilaian resiko keselamatan konstruksi pada penelitian ini menggunakan metode HIRARC.Berdasarkan hasil penilaian dan pengolahan datadiperoleh 7 (tujuh) jenis resiko dengan level yang sangat tinggi (extreme), (41\%), yaitu tertimpa bore pile, tangan atau kaki bisa terkilir atau patah, tertimpa material dari ketinggian, tangan atau kaki bisa terkilir atau patah dan percikan api yang menimbulkan kebakaran, untuk level risiko tinggi (high) (59\%) diperoleh 10 (sepuluh) jenis resiko, yaitu pekerja atau alat berat jatuh kedalam galian, mata tekena percikan api dan asap, alat berat menabrak fasilitas sekitar, tangan terjepit ketika pembengkokanbesi, gangguan pernafasan akibat debu pasir dan semen. Sedangkan pengendalian risikonya menggunakan metode hirarki pengendalian (hirarchy of control), yaitu: eliminasi, substitusi, rekayasa (engineering), administratif, dan Alat Pelindung Diri $(A P D)$.
\end{abstract}

Kata kunci: resiko, K3 Konstruksi, HIRARC, proyek, konstruksi

\section{PENDAHULUAN}

Proyek pembangunan Asrama Haji Padang Pariaman dimaksudkan untuk penambahan bangunan baru dan peningkatan fasilitas haji karena dari waktu ke waktu kuota jamaah haji di Sumatra Barat terus meningkat maka dibuatlah tempat yang lebih besar dan nyaman untuk para jamaah haji. Peneliti memilih objek studi kasus yakni Proyek Pembangunan Asrama Haji dimana PT. RP selaku kontraktor pelaksana dari proyek tersebut. Berdasarkan observasi lapangan, masih banyak pekerja yang tidak menggunakan Alat Pelindung Diri (APD) lengkap, pengelolaan lingkungan kerja yang tidak memadai karena adanya penumpukan material dan akses keluar masuknya barang yang dapat menganggu kelancaran mobilitas dilokasi proyek, serta masih ada pekerjaan-pekerjaan yang terbengkalai akibat pembangunan yang tertunda karena pergantian kontraktor pelaksana. Mengingat permasalahan-permasalahan tersebut, dibutuhkan identifikasi penerapan SMKK yang dilaksanakan oleh kontraktor pelaksana serta menganalisis risiko keselamatan konstruksi pada proyek tersebut.
Menurut Permen PUPR No.21 Tahun 2019 Tentang Pedoman Sistem Manajemen Keselamatan konstruksi, keselamatan konstruksi adalah segala kegiatan keteknikan untuk mendukung Pekerjaan konstruksi dalam mewujudkan pemenuhan standar keamanan, keselamatan, kesehatan dan keberlanjutan yang menjamin keselamatan keteknikan konstruksi, keselamatan dan kesehatan tenaga kerja, keselamatan publik dan lingkungan.Keselamatan dan kesehatan kerja konstruksi yang selanjutnya disebut K3 Konstruksi adalah segala kegiatan untuk menjamin dan melindungi keselamatan dan kesehatan tenaga kerja melalui upaya pencegahan kecelakaan kerja dan penyakit akibat kerja pada pekerjaan konstruksi.

Pada setiap kegiatan konstruksi, selalu ada kemungkinan kecelakaan-kecelakaan selalu dapat terjadi karena berbagai sebab. Kecelakaan adalah kejadian yang merugikan yang tidak terduga dan tidak di harapkan dan tidak ada unsur kesengajaan. Kecelakaan kerja dimaksudkan sebagai kecelakaan yang terjadi di tempat kerja, yang diderita oleh pekerja dan kecelakaan kerja dapat di sebabkan oleh dua faktor penyebab yakni: a) Tindakan perbuatan 
manusia yang tidak memenuhi standar keselamatan (Unsafe Acts), b) Keadaan-keadaan lingkungan yang tidak aman (Unsafe Condition). Walaupun manusia telah berhati-hati, namun apabila lingkungan tidak amanmaka kecelakaan dapat mungkin terjadi, begitu pula sebaliknya. Oleh karena itulah diperlukan pedoman bagaimana bekerja memenuhi prinsip-prinsip keselamatan [1].

Menurut PMBOK Guide 5th Edition menjelaskan manajemen risiko proyek sebagai proses perencanaan, pengidentifikasian, penganalisisan, perencanaan penanganan dan pengendalian terhadap risiko yang terdapat di suatu proyek. Manajemen resiko adalah suatu pendekatan terstruktur/metodologi dalam mengelola ketidakpastian yang berkaitan dengan ancaman, suatu rangkaian aktivitas manusia termasuk ; penilaian risiko, pengembangan strategi untuk mengelolanya dan mitigasi risiko denganmenggunakan

pemberdayaan/pengelolaan sumberdaya. Strategi yang dapat diambil antara lain adalah memindahkan risiko kepada pihak lain, menghindari risiko, mengurangi efek negatif risiko, dan menampung sebagian atau semua konsekuensi risiko tertentu. Proses yang dilalui dalam manajemen risiko [2] adalah:

a) Penetapan konteks merupakan perencanaan meliputi langkah memutuskan bagaimana mendekati dan merencanakan aktivitas manajemen risiko untuk proyek.

b) Identifikasi Risiko, tahapan selanjutnya dari proses identifikasi risiko adalah mengenali jenis-jenis risiko yang mungkin (dan umumnya) dihadapi oleh setiap pelaku bisnis.

c) Analisis Risiko Kualitatif, analisis kualitatif dalam manajemen risiko adalah proses menilai (assessment) impak dan kemungkinan dari risiko yang sudah diidentifikasi. Analisis Risiko Kuantitatif adalah proses identifikasi secara numeric probabilitas dari setiap risiko dan konsekuensinya terhadap tujuan proyek.

d) Perencanaan Respon Resiko, Risk response planning adalah proses yang dilakukan untuk meminimalisasi tingkat risiko yang dihadapi sampai batas yang dapat diterima.

e) Pengendalian dan Monitoring Risiko, langkah ini adalah proses mengawasi risiko yang sudah diidentifikasi, memonitor risiko yang tersisa, dan mengidentifikasikan risiko baru, memastikan pelaksanaan risk management plan dan mengevaluasi keefektifannya dalam mengurangi risiko.

Metode Hazard Identification Risk Assessment and Risk Control (HIRARC) merupakanrangkaian proses identifikasi bahaya pekerjaan dalam aktivitasrutin dan non rutin. Identifikasi bahaya,penilaian risiko dan pengendaliannya merupakanbagian sistem manajemen risiko yang merupakanelemendari SMKK, yang mencakupidentifikasi bahaya (hazard identification), penilaianrisiko (risk assessment) dan pengendalian risiko (Risk Control). Menurut AS/NZS 4360:1999, resiko (risk) adalah peluang terjadinya sesuatu yang mempunyai dampak terhadap sasaran, diukur dengan hokum sebab akibat. Risiko diukur berdasarkan nilai likelihood dan consequence. Penilaian risko (Risk Assessment) adalah proses penilaian yang digunakan untuk mengidentifikasi potensi bahaya yang dapat terjadi. Tujuan dari risk assessment adalah memastikan kontrol risiko dari proses, operasi atau aktifitas yang dilakukan berada pada tingkat yang dapat diterima. Penilaian dalam risk assessment yaitu Likelihood (L) dan Severity (S) atau Consequence (C). Likelihood menunjukkan seberapa mungkin kecelakaan itu terjadi, sedangkan Severity atau Consequence menunjukkan seberapa parah dampak dari kecelakaan tersebut. Nilai dari Likelihood dan Severity digunakan untuk menentukan Risk Rating atau Risk Level. Berikut ini merupakan tabel consequence, table likelihood dan risk matrix menurut standar AS/NZS 4360:1999 dapat dilihat pada tabel 1, 2 dan 3 [3].Risiko diformulasikan sebagai fungsi dari kemungkinan terjadi (likelihood) dan dampak negatif (impact). Indeks risiko $=$ probabilitas $($ Likelihood $) \times$ Dampak (Impact)(1)

Tabel 1. Kriteria Consequense

\begin{tabular}{|c|c|c|}
\hline Level & Kriteria & Penjelasan \\
\hline 1 & $\begin{array}{c}\text { Insignificatio } \\
n\end{array}$ & $\begin{array}{c}\text { Tidakterjadi cidera, } \\
\text { kerugian } \\
\text { finansialkecil }\end{array}$ \\
\hline 2 & Minor & $\begin{array}{c}\text { P3K, } \\
\text { penangananditempat } \\
\text { dan kerugian } \\
\text { finansialsedang }\end{array}$ \\
\hline 3 & Moderate & $\begin{array}{c}\text { Cideraberat, } \\
\text { kehilangankemamp } \\
\text { uanproduksi, } \\
\text { Penangananluar } \\
\text { areatanpaefek } \\
\text { negatif,kerugianfina }\end{array}$ \\
\hline
\end{tabular}




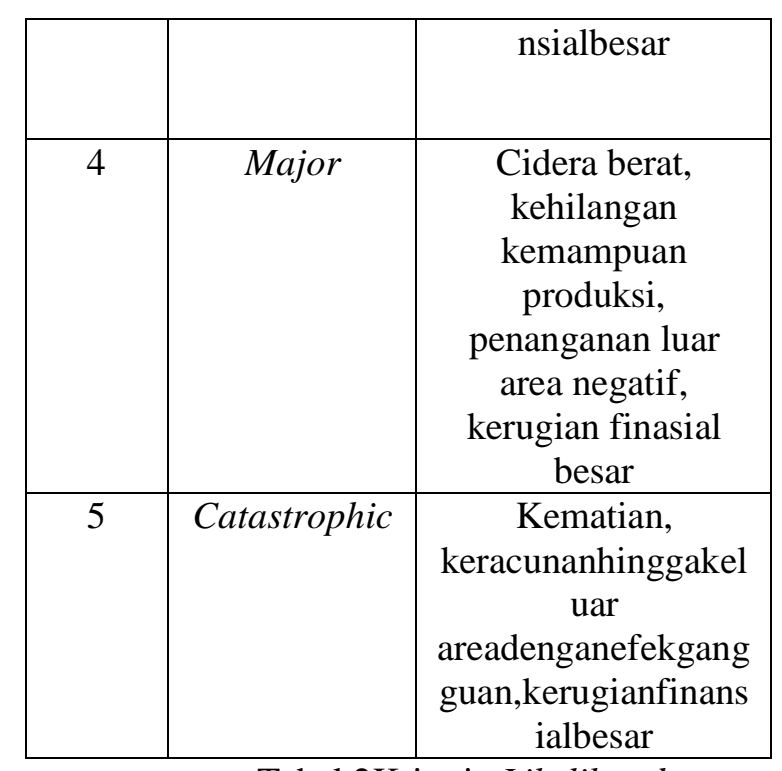

\begin{tabular}{|c|c|c|}
\hline \multicolumn{3}{|r|}{ Tabel 2Kriteria Likelihood } \\
\hline $\begin{array}{c}\text { Lev } \\
\text { el }\end{array}$ & $\begin{array}{c}\text { Kete } \\
\text { ria }\end{array}$ & Penjelasan \\
\hline 1 & $\begin{array}{c}\text { Almo } \\
\text { st } \\
\text { Certa } \\
\text { in }\end{array}$ & Terjadihamperdisemuakeadaan \\
\hline 2 & $\begin{array}{c}\text { Likel } \\
y\end{array}$ & $\begin{array}{l}\text { Sangatmungkinterjadihamperdi } \\
\text { semuakeadaan }\end{array}$ \\
\hline 3 & $\begin{array}{l}\text { Possi } \\
\text { ble }\end{array}$ & Dapatterjadisewaktu-waktu \\
\hline 4 & $\begin{array}{l}\text { Unlik } \\
\text { ely }\end{array}$ & Kemungkinan jarang terjadi \\
\hline 5 & Rare & $\begin{array}{l}\text { Hanyadapatterjadi pada } \\
\text { keadaantertentu }\end{array}$ \\
\hline
\end{tabular}

Tabel. 3 Matriks Resiko

\begin{tabular}{|c|c|c|c|c|c|}
\hline \multirow{2}{*}{ Likelihood } & \multicolumn{5}{|c|}{ Consequence } \\
\cline { 2 - 6 } & $\mathrm{H}$ & 2 & 3 & 4 & 5 \\
\hline 5 & $\mathrm{H}$ & $\mathrm{H}$ & $\mathrm{E}$ & $\mathrm{E}$ & $\mathrm{E}$ \\
\hline 4 & $\mathrm{M}$ & $\mathrm{H}$ & $\mathrm{H}$ & $\mathrm{E}$ & $\mathrm{E}$ \\
\hline 3 & $\mathrm{~L}$ & $\mathrm{M}$ & $\mathrm{H}$ & $\mathrm{E}$ & $\mathrm{E}$ \\
\hline 2 & $\mathrm{~L}$ & $\mathrm{~L}$ & $\mathrm{M}$ & $\mathrm{H}$ & $\mathrm{E}$ \\
\hline 1 & $\mathrm{~L}$ & $\mathrm{~L}$ & $\mathrm{M}$ & $\mathrm{H}$ & $\mathrm{H}$ \\
\hline
\end{tabular}

Pengendalian risiko (risk control) adalah cara untuk mengatasi potensi bahaya yang terdapat dalam dalam lingkungan kerja. Potensi bahaya tersebut dapat dikendalikan dengan menentukan suatu skala prioritas terlebih dahulu yang kemudian dapat membantu dalam prioritas terlebih dahulu yang kemudian dapat membantu dalam pemilihan pengendalian resiko yang disebut hirarki pengendalian resiko [4]. Pengendalian risiko dapat mengikuti pendekatan hirarki pengendalian (Hirarchy of Control). Hirarki pengedalian resiko adalah suatu urutanurutan dalam pencegahan dan pengendalian resiko yang mungkin timbul yang terdiri dari beberapa tingkatan secara berurutan. Hirarki atau metode yang dilakukan untuk mengendalikan risiko antara lain [3]:

a) Eliminasi (Elimination)

Eliminasi dapat didefinisikan sebagai upaya menghilangkan bahaya. Eliminasi merupakan langkah ideal yang dapat dilakukan dan harus menjadi pilihan utama dalam melakukan pengendalian risiko bahaya. Hal ini berarti eliminasi dilakukan dengan upaya mengentikan peralatan atau sumber yang dapat menimbulkan bahaya.

b) Substitusi (Substitution)

Substitusi didefinisikan sebagai penggantian bahan yang berbahaya dengan bahan yang lebih aman. Prinsip pengendalian ini adalah menggantikan sumber risiko dengan sarana atau peralatan lain yang lebih aman atau lebih rendah tingkat resikonya.

c) Rekayasa (Engineering)

Rekayasa / Engineering merupakan upaya menurunkan tingkat risiko dengan mengubah desain tempat kerja, mesin, peralatan atau proses kerja menjadi lebih aman. Ciri khas dalam tahap ini adalah melinatkan pemikiran yang lebih mendalam bagaimana membuat lokasi kerja yang memodifikasi peralatan, melakukan kombinasi kegiatan, perubahan prosedur, dan mengurangi frekuansi dalam melakukan kegiatan berbahaya.

d) Administrasi (Administrative)

Dalam upaya sacara administrasi difokuskan pada penggunaan prosedur seperti SOP (Standard Operating Procedure) sebagai langkah mengurangi tingkat risiko.

e) Alat Pelindung Diri (safety tools)

Alat pelindung diri merupakan langkah berakhir yang dilakukan yang berfungsiuntuk mengurangi keparahan akibat dari bahaya yang ditimbulkan.

\section{METODE PENELITIAN}

Proyek Pembangunan Gedung Asrama Haji Padang Pariaman sebagai objek dari penelitian ini. Proyek ini berlokasi di Kabupaten Padang Pariaman. Penelitian ini dimulai dari bulan Februari 2019 hingga bulan Juli 2019. Metode 
penelitian adalah metodedeskriptif. Tujuan penelitian ini adalah mendeskripsikan sejumlah variabel yang berkenaan dengan masalah dan bagian yang diteliti terhadap fenomena yang diuji. Dalam penelitian ini, teknik yang digunakan untuk mengumpulkan data penelitian, yaitu dengan observasi di lapangan, wawancara, kuesioner sebagai instrumen penelitian untuk memperoleh informasi dan data dengan menyusun seperangkat pertanyaan atau pernyataan tertulis kepada responden. Teknik pengambilan sampel dalam penelitian menggunakan purposive sampling method yakni memilih nara sumber untuk diwawancarai dan responden untuk mengisi kuisioner terhadap orang-orang yang berkapabilitas dan berada di posisi yang memahami K3 di proyek tersebut. Nara sumber untuk mendapatkan informasi dan data adalah engineer lapangan, $\mathrm{K} 3$ engineer dan manajer proyek, sedangkan untuk responden kuisioner sebanyak 30 orang dengan jabatan Direktur Teknik, engineer, konsultan pengawas, dan mandor. Kuisioner dilakukan untuk mengidentifikasikan sumber bahaya kecelakaan kerja dan menetapkan variabel resiko melalui pengolahan data dengan menggunakan SPSS versi 2.1, sedangkan untuk penilaian resiko dengan metode HIRARC dilakukan oleh 12 orang yang berkompeten untuk menjawab permasalahan K3 Konstruksi pada proyek tersebut. Tahapan penelitian adalah sebagai berikut :

a. Studi Literatur

Studi literatur dimaksudkan dalam penelitian adalah untuk menyusun teori-teori tentang Sistem Manajemen Keselamatan dan Kesehatan Kerja Konstruksi (K3K),peraturan tentang SMK3K, Manajemen Resiko, Metode HIRARC dan melakukan studi terhadap penelitian-penelitian terdahulu.

b. Studi Pendahuluan

Sebelum merumuskan permasalahan penelitian, maka penulis melakukan tinjauan lapangan, mengamati kondisi yang terkait penerapan $\mathrm{K} 3 \mathrm{~K}$ serta mengamati potensi sumber bahaya yang ada di lingkungan proyek.

c. Perumusan Masalah

Berdasarkan studi pendahuluan ini maka dirumuskan masalah penelitian.

d. Identifikasi penerapan SMK3K dan Sumber Bahaya Kecelakaan Kerja

Dalam penelitian ini, penulis mengumpulkan data dan informasi melalui observasi lapangan dan wawancara untuk mengetahui bagaimana penerapan $\mathrm{SMk} 3 \mathrm{~K}$ pada proyek tersebut serta mengobservasi sumber bahaya $\mathrm{K} 3$ pada semua rangkaian kegiatan konstruksi di lokasi proyek.

e. Penyusunan dan Penyebaran Kuisioner

Menyusun dan menyebarkan kuesioner untuk menetapkan variabel resiko K3. Kuesioner disebarkan kepada 30 responden dan kemudian melakukan pengujian variabel melalui uji vadilitas dan reliabilitas menggunakan software SPSS versi 2.1.

f. Penetapan Resiko KK

Setelah variabel resiko K3 dinyatakan valid dan reliabel maka ditetapkan jenis-jenis resiko K3 untuk selanjutnya disusun formulir penilaian metode HIRARC untuk menentukan Likelihood dan Consequense dari masing-masing resiko $\mathrm{K} 3$ tersebut terhadap 12 narasumber yang berkompeten.

g. Penilaian Tingkat Resiko dan Pengendalian Resiko HIRARC

Penilaian HIRARC bermaksud untuk pencegahan dan pengurangan potensi terjadinyakecelakaan kerja, menghindari dan meminimalkanrisiko yang terjadi secara tepat dengan caramenghindari dan meminimalkan risiko terjadinyakecelakaan kerja serta pengendaliannya dalamrangka melakukan proses kegiatan sehingga prosesnya menjadi aman. Identifikasi bahaya,penilaian risiko dan pengendaliannya merupakantahapan penilaian menggunakan metode ini, yang terdiri dariidentifikasi bahaya (hazard identification), penilaianrisiko (risk assessment) dan pengendalian risiko (Risk Control) [3].

Rata-rata peluang $=\frac{\sum_{1}^{n} \text { peluang }}{\text { Jumlah responden }(n]}$

Rata-rata dampak $=\frac{\sum_{1}^{n} \text { Dampak }}{\text { Jumlah responden }(n]}$

Risiko $=\frac{\sum_{1}^{n} \text { peluangxDampak }}{\text { Jumlah responden }(n]}$

Pengendalian resikodilakukan dengan cara mengendalikan setiap sumber-sumber potensi bahaya ditempat kerja dengan pengendalian bahaya atau risiko dapat di ukur dengan 
hukum sebab akibat. Resiko di ukur berdasarkan nilai likelihood dan consequence. Likelihood menunjukan beberapa mungkin ecelakaan itu terjadi, sedangkan Severty atau Concequence menunjukan seberapa parah dampak dari kecelakaan tersebut. Nilai dari ikelihood dan Severty atau Concequence di gunakan untuk menetukan Risk Rating atau Risk Level.

h. Pembahasan

Pada tahapan ini adalah memberikan analisis terhadap hasil yang ditemui dalam penelitian dan hasil pengolahan data penilaian dalam rangka tercapainya tujuan penelitian.

Dalam pelaksanaan penelitian di susun suatu bagan alir penelitian yang dapat diilustrasikan pada Gambar 1 di bawah ini.

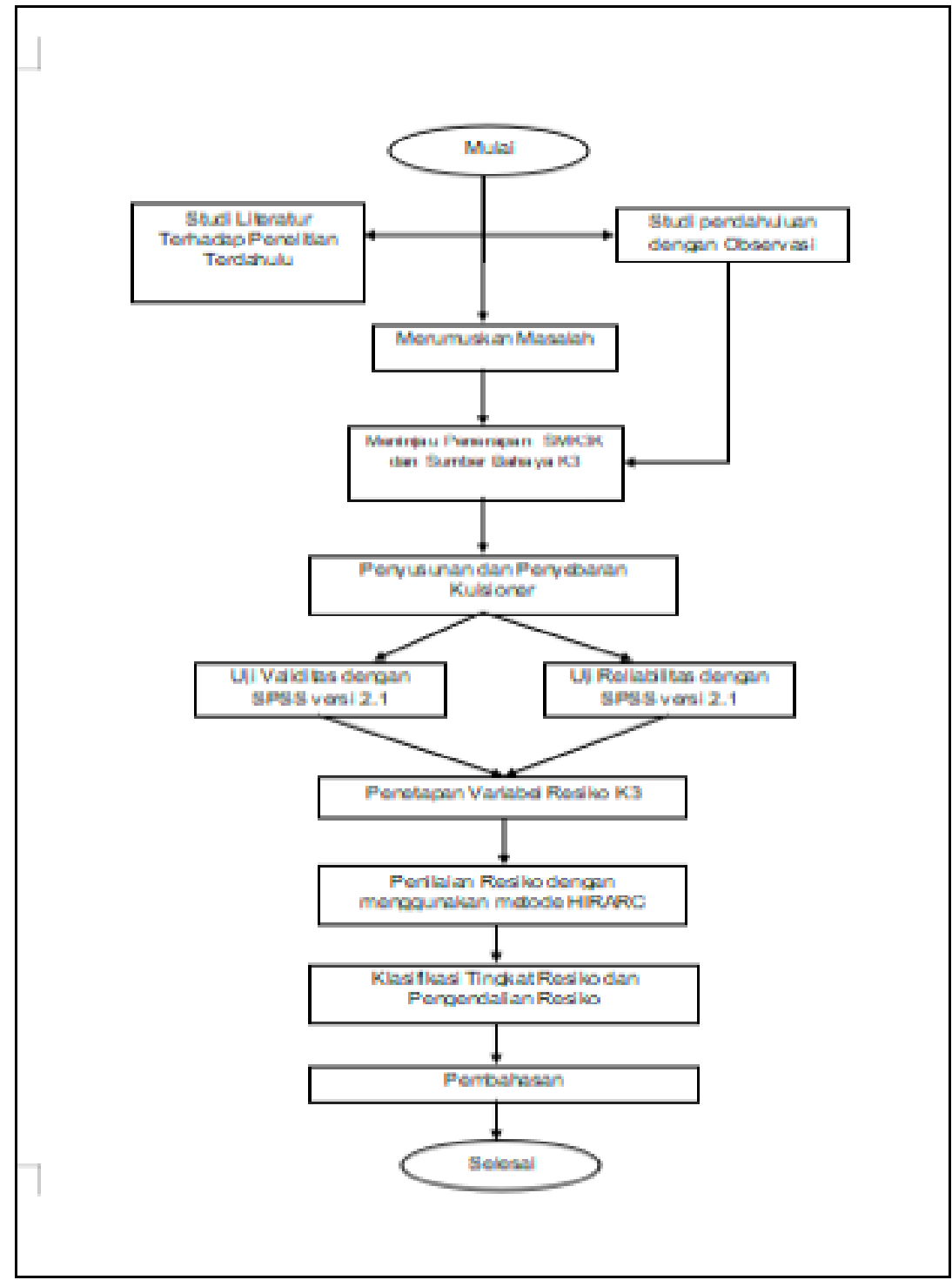

Gambar 1 Bagan Alir Penelitian

HASIL DANPEMBAHASAN

Penerapan SMKK

Berdasarkan hasil wawancara dan pengumpulan beberapa dokumen terkait $\mathrm{KK}$ kepada beberapa narasumber didapatkan bahwa kontraktor pelaksana tidak menyiapkan dokumen RKK yang jelas dan lengkap, dibuktikan tidak dijelaskan komitmen manajemen KK, analsisi keselamatan pekerjaan (Job Safety Analysis) tidak memadaidan itemitem yang lain yang dimuat dalam suatu dokumen RKK. Penerapan SMKK hanya dilakukan denganpertemuan pagi 
hari (safety morning) dan pemeriksaan Alat Pelindung Diri (APD) bagi pekerja sebelum memulai aktivitas proyek. Dokumen harus dilengkapi berdasarkan lingkup pekerjaan dan kondisi di lapangan sebelum pelaksanaan pekerjaan dimulai dan disampaikan, dibahas, disepakati, dan disetujui oleh Pengguna Jasa dan Kontraktor pada saat rapat persiapan pelaksanaan Pekerjaan Konstruksi (preconstruction meeting).Berikut beberapa item-item yang diusulkan kepada kontraktor dalam menyusun dokumen kedepannya berdasarkan standar RKK yang disusun oleh Dirjen Bina Konstruksi Kementrian PUPR [9] antara lain ;

A. Kepedulian Pimpinan Terhadap Isu Eksternal dan Internal mencakup;

i. Isu internal mencakup kemampuan dan pemahaman dalam hal sumber daya, pengetahuan, dan kompetensi (seperti modal, waktu, sumber daya manusia, proses, sistem, dan teknologi), pengaturan waktu kerja, hubungan serta persepsi dan nilai-nilai dari pekerja, kebijakan, tujuan, dan strategi untuk mencapainya serta tata kelola, struktur organisasi, peran dan akuntabilitas, kondisi kerja, dsb. Sedangkan isu eksternal mencakup lokasi pekerjaan, sosial, budaya, teknologi, dan alam, berkaitan dengan subkontraktor, pemasok, mitra dan penyedia, teknologi baru, dan munculnya pekerjaan baru, pengetahuan baru tentang produk dan pengaruhnya terhadap kesehatan dan keselamatan, hubungan dengan kepentingan pengguna jasa terkait dengan pekerjaan konstruksi, dan perubahan dan lain-lain yang terkait.

ii. Unit Keselamatan Konstruksi, memuat bagan struktur organisasi yang dapat menjelaskan hubungan koordinasi antara Pelaksana Konstruksi, Kantor Pusat dan pengelola SMKK.Tanggung jawab Unit Keselamatan Kerja antara lain ; Hubungan kerja antara Tim Pelaksana Pekerjaan Konstruksi dan Kantor Pusat Penyedia Jasa, Tugas, tanggung jawab dan wewenang Tim Pelaksana Pekerjaan Konstruksi dan Kantor Pusat Penyedia Jasa, Jadwal pelaporan kinerja pelaksanaan pekerjaan, Kendala yang dihadapi terkait pelaksanaan pekerjaan khususnya terkait masalah Keselamatan
Konstruksi dan alternatif solusi pemecahan masalah tersebut yang membutuhkan bantuan dukungan dari pimpinan puncak Penyedia Jasa di Kantor Pusat.

B. Komitmen Keselamatan Konstruksi

Mencakup lembar pakta komitmen, lembar kebijakan keselamatan konstruksi, tinjauan pelaksanaan komitmen, konsultansi dan partisipasi pekerja

C. Identifikasi Bahaya, Penilaian Resiko, Pengendalian dan Peluang

Mencakup penyusunan jadwal pelaksanaan pekerjaan, mengenali bahaya, penilaian risiko, dan peluang (IBRP) dan analisis keselamatan kerja (job safety analysis). Dalam mengenali bahaya perlu mengenali mana pekerjaan yang rutin (terdapat dalam daftar kuantitas pekerjaan/rincian kerja) dan mana yang merupakan pekerjaan nonrutin (yang tidak terdapat dalam daftar kuantitas pekerjaan/rincian kerja) kemudian dilanjutkan dengan menetapkan kriteria tingkat kekerapan, tingkat keparahan, dan tabel penetapan tingkat risiko.

D. Sasaran dan Program Keselamatan Konstruksi

Memuat tabel sasaran dan program berdasarkan identifikasi bahaya, penilaian risiko yang bersifat umum, memuat tabel sasaran dan program berdasarkan identifikasi bahaya, penilaian risiko dan peluang yang bersifat khusus (skala prioritas sedang dan tinggi), mengidentifikasi peraturan perundangan dan persyaratan lainnya yang harus dijalankan hingga pasal atau klausul yang berhubungan langsung dengan program diuraikan menurut identifikasi bahaya, penilaian risiko dan peluang.

E. Dukungan Keselamatan Konstruksi

Menetapkan sumber daya, kompetensi, kepedulian, komunikasi dan informasi terdokumentasi. Sumber daya mencakup peralatan (Surat Ijin Kelaikan Operasi (SILO) pesawat angkat \& angkut (alat berat), Sertifikat kelaikan peralatan konstruksi lainnya, dan daftar peralatan utama), material (data keselamatan bahan terkait pengendalian bahan berbahaya dan beracun/B3), biaya SMK3, sertifikasi kompetensi kerja, komunikasi (induksi, pertemuan pagi hari, pertemuan kelompok kerja (toolbox meeting), rapat keselamatan 
konstruksi, penerapan informasi bahayabahaya dan jadwal program komunikasi,

F. Rencana dan Operasi Keselamatan Konstruksi

i. Perencanaan dan pengendalian operasi Mencakup struktur organisasi pelaksanaan dan unit keselamtan konstruksi, pengelolaan keselamatan lingkungan kerja (mutu bahan, metode pekerjaan konstruksi, izin kerja), pengelolaan keselamatan lalu lintas, pengamanan lingkungan kerja dan izin keluar masuk barang. Izin kerja meliputi JSA, prosedur sistem keamanan kerja, lembar inspeksi kerja, dan formulir izin kerja. Mutu peralatan mencakup; prosedur penggunaan alat berat/peralatan, memiliki label laik operasi, dan prosedur penggunaan Alat Pelindung Diri (APD).

ii. Kesiapan tanggap terhadap kondisi darurat

Mencakup daftar instruksi kerja dan kesiap siagaan dan tanggap terhadap kondisi darurat. Tanggap darurat sesuai dengan sifat dan klasifikasi Pelaksanaan Pekerjaan Konstruksi yang dikerjakan dan ditandatangani oleh Ahli Teknik terkait dan Penanggung Jawab Keselamatan Konstruksi.

Penyelidikan insiden (kecelakaan, kejadian berbahaya, dan penyakit akibat kerja) yang ditanda tangani oleh Penanggung Jawab Keselamatan dan Konstruksi Kepala Pelaksana Pekerjaan Konstruksi.

G. Pemantauan dan Evaluasi

i. Melakukan inspeksi (mencakup prosedur dan/atau petunjuk kerja inspeksi, format lembar periksa lingkup pekerjaan, pesawat angkat \& angkut, perkakas, bahan/material, lingkungan, kesehatan, dan keamanan), audit (mencakup prosedur dan/atau petunjuk kerja audit internal diterapkan berkala oleh pelaksana pekerjaan konstruksi melibatkan auditor independen,sekurang-kurangnya 1 kali dalam 1 pelaksanaan/untuk pekerjaan konstruksi tahun jamak mengikuti peraturan perundangan yang berlaku) dan patroli keselamatan konstruksi (mencakup prosedur dan/atau petunjuk kerja patroli keselamatan konstruksi, patroli dilakukan oleh seluruh pimpinan perusahaan (penyedia jasa, pengawas, subkontraktor) dan pengguna jasa.

ii. Tinjauan Manajemen

Memuat prosedur dan/atau petunjuk kerja terkait pelaksanaan tinjauan manajemen yang bertujuan untuk meningkatkan kinerja keselamatan konstruksi. Tinjauan manajemen dilakukan sekurang-kurangnya berdasarkan hasil audit atau kecelakaan kerja pada pekerjaan konstruksi yang menyebabkan fatality.

iii. Peningkatan Kinerja Keselamatan Konstruksi

Memuat format tindakan perbaikan untuk pelaksanaan pekerjaan konstruksi pada kontrak tahun jamak. Penyedia Jasa memastikan program peningkatan kinerja keselamatan konstruksi berdasarkan hasil Tinjauan Manajemen ditindaklanjuti pada pekerjaan konstruksi yang akan datang.

\section{Penilaian dan Pengendalian Resiko KK}

Dalam menganalisa variabel-variabel risiko KK yang terjadi, maka perlu identifikasi kondisi-kondisi kemungkinan yang menimbulkan risiko. Sumber-sumber bahaya diidentifikasi dari setiap kegiatan konstruksi melalui observasi lapangan dan tinjauan penelitian terdahulu. Berikut ini adalah contoh hasil dari identifikasi rsiko $\mathrm{KK}$, dapat dilihat pada tabel 4 berikut ini.

Tabel 4Variabel Risiko K3

\begin{tabular}{|l|l|l|}
\hline No & \multicolumn{1}{|c|}{ Kegiatan Konstruksi } & \multicolumn{1}{c|}{ Resiko KK } \\
\hline 1 & $\begin{array}{l}\text { Galian tanah /Timbunan dengan } \\
\text { Excavator }\end{array}$ & Pekerja atau alat berat jatuh kedalam galian \\
\hline 2 & Aktifitas pemotongan & Mata terkena percikan api dan asap \\
\hline 3 & Pekerjaan pondasi bore pile & Tertimpa bore pile \\
\hline 4 & $\begin{array}{l}\text { Galian/timbunan dengan } \\
\text { mengguanakan alat berat }\end{array}$ & Alat berat menbrak fasilitas sekitar \\
\hline
\end{tabular}




\begin{tabular}{|c|c|c|}
\hline 5 & Galian Manual & Tertimpa material jatuh ketika di angkat \\
\hline 6 & Pekerjaan Scafolding & Tagan atau kaki bisa terkilir atau patah \\
\hline 7 & $\begin{array}{l}\text { Lifting material dengan tower } \\
\text { crane }\end{array}$ & Tertimpa material dari ketinggian \\
\hline 8 & Pekerjaan pembuatan bekisting & Tertimpa material.ketika di pasangkan \\
\hline 9 & Pekerjaan pembongkarBekisting & Tagan atau kaki bisa terkilir atau patah \\
\hline 10 & Pekerjaan pembesian & Tangan terjepit ketika membengkokan besi \\
\hline 11 & Pekerjaan pengecoran & Tertimpa bahan material. \\
\hline 12 & $\begin{array}{l}\text { Pemasangan Rangka atap dan } \\
\text { penutu patap }\end{array}$ & Tagan atau kaki bisa terkilir atau patah \\
\hline 13 & 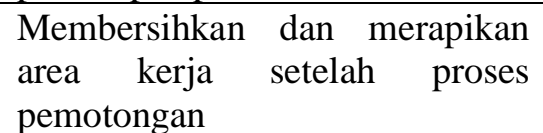 & Gangguan pada saluran pernafasan \\
\hline 14 & $\begin{array}{l}\text { Mengecek kembali material yang } \\
\text { telah di potong }\end{array}$ & Tangan melupuh atau luka bakar ringan \\
\hline 15 & Pemasangan dinding pelesteran & Gangguan pernafasan akibat debu pasir dan semen \\
\hline 16 & Pemasangan keramik & Pekerja terluka akibat terkena potongan keramik \\
\hline 17 & Instalasi listrik & Terdapat percikan api menimbulkan kebakaran \\
\hline
\end{tabular}

Penilaian risiko berdasarkan metode HIRARC diperoleh melaluiwawancara kepada 12 nara sumber yang berkompeten memberikan jawaban dan memahami permasalahan yang ditanyakan. Kuisioner berisikan penilaian probabilitas kemungkinan terjadi (likelihood) dan dampak yang ditimbulkan akibat resiko (consequences).
Berdasarkan rumus indeks resiko adalah jumlah perkalian Likelyhood dan Consequence dibagi dengan jumlah narasumber yang mengisi kuisioner tersebut. Berikut hasil perhitungan indeks resiko dari setiap kegiatan konstruksi yang dapat dilihat pada Tabel 5 dibawah ini.

Tabel 5 Hasil Perhitungan Nilai Indeks dan Tingkat Resiko

\begin{tabular}{|c|l|l|c|l|}
\hline No & \multicolumn{1}{|c|}{ Proses } & \multicolumn{1}{|c|}{ Resiko KK } & \multicolumn{1}{|c|}{$\begin{array}{c}\text { Nilai } \\
\text { Indeks } \\
\text { Resiko } \\
\text { KK }\end{array}$} & \multicolumn{1}{|c|}{$\begin{array}{c}\text { Tingkat } \\
\text { Resiko }\end{array}$} \\
\hline 1 & $\begin{array}{l}\text { Galian tanah /Timbunan dengan } \\
\text { Excavator }\end{array}$ & $\begin{array}{l}\text { Pekerja atau alat berat } \\
\text { jatuh kedalam galian }\end{array}$ & 7 & High \\
\hline 2 & Aktivitas pemotongan & $\begin{array}{l}\text { Mata terkena percikan api } \\
\text { dan asap }\end{array}$ & 10,17 & Extreme \\
\hline 3 & Pekerjaan pondasi bore pile & Tertimpa bore pile & 15,33 & Extreme \\
\hline 4 & $\begin{array}{l}\text { Galian/timbunan dengan } \\
\text { mengguanakan alat berat }\end{array}$ & $\begin{array}{l}\text { Alat berat menbrak } \\
\text { fasilitas sekitar }\end{array}$ & 7,67 & High \\
\hline 5 & $\begin{array}{l}\text { Galian Manual } \\
\text { Rertimpa material jatuh } \\
\text { ketika di angkat }\end{array}$ & 6,25 & High \\
\hline 7 & $\begin{array}{l}\text { Pekerjaan Scafolding } \\
\text { Lifting material dengan tower } \\
\text { crane }\end{array}$ & $\begin{array}{l}\text { Tagan atau kaki bisa } \\
\text { terkiliratau patah } \\
\text { ketinggian material dari }\end{array}$ & 13,50 & Extreme \\
\hline 8 & Pekerjaan pembuatan bekisting & $\begin{array}{l}\text { Tertimpa material.ketika } \\
\text { di pasangkan }\end{array}$ & 7,50 & High \\
\hline
\end{tabular}




\begin{tabular}{|c|c|c|c|c|}
\hline 9 & $\begin{array}{ll}\text { Pekerjaan } & \text { pembongkaran } \\
\text { Bekisting } & \end{array}$ & $\begin{array}{l}\text { Tagan atau kaki bisa } \\
\text { terkilir atau patah }\end{array}$ & 8,67 & High \\
\hline 10 & Pekerjaan pembesian & $\begin{array}{l}\text { Tangan terjepit ketika } \\
\text { membengkokan besi }\end{array}$ & 9,42 & Extreme \\
\hline 11 & Pekerjaan pengecoran & Tertimpa bahan material. & 5,92 & High \\
\hline 12 & $\begin{array}{l}\text { Pemasangan Rangka atap dan } \\
\text { penutu patap }\end{array}$ & $\begin{array}{l}\text { Tagan atau kaki bisa } \\
\text { terkilir atau patah }\end{array}$ & 14,75 & Ekstrim \\
\hline 13 & $\begin{array}{l}\text { Membersihkan } \text { dan merapikan } \\
\text { area kerja } \\
\text { pemotongan }\end{array}$ & $\begin{array}{l}\text { Gangguan pada saluran } \\
\text { pernafasan }\end{array}$ & 5,83 & High \\
\hline 14 & $\begin{array}{l}\text { Mengecek kembali material yang } \\
\text { telah di potong }\end{array}$ & $\begin{array}{l}\text { Tangan melupuh atau } \\
\text { luka bakar ringan }\end{array}$ & 7,25 & High \\
\hline 15 & Pemasangan dinding pelesteran & 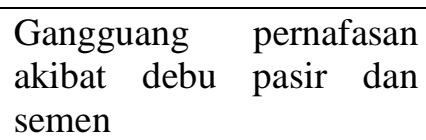 & 6,58 & High \\
\hline 16 & Pemasangan keramik & $\begin{array}{l}\text { Pekerja terluka akibat } \\
\text { terkena potongan keramik }\end{array}$ & 8,50 & High \\
\hline 17 & Instalasi listrik & $\begin{array}{l}\text { Terdapat percikan api } \\
\text { menimbulkan kebakaran }\end{array}$ & 15,58 & Ekstrim \\
\hline
\end{tabular}

Terdapat 17 (tujuh belas) kegiatan konstruksipada proyek Pembangunan Asrama Haji Padang Pariaman yang memiliki resiko K3 dengan tingkat resiko ekstrim dan tinggi (high). Nilai risiko yang terdapat dalam resiko ekstrim sebanyak $41 \%$ sedangkan resiko tinggi (high) sebanyak 59\%. Hirarki pengendalian resiko adalah suatu urutan-urutan dalam pencegahan dan pengendalian resiko yang mungkin timbul yang terdiri dari beberapa tingkatan secara berurutan. Berikut ini adalah contoh hasil dari pengendalian risiko dapat dilihat pada Tabel 6 di bawah ini.

Tabel 6 Pengendalian Risiko Keselaatan Konstruksi

\begin{tabular}{|l|l|l|c|c|l|l|}
\hline No & \multicolumn{1}{|c|}{ Kegiatan } & Resiko KK & $\begin{array}{c}\text { Inde } \\
\text { ks } \\
\text { Nilai } \\
\text { Resik } \\
\mathbf{0}\end{array}$ & $\begin{array}{c}\text { Tingk } \\
\text { at } \\
\text { Resik } \\
\mathbf{0}\end{array}$ & $\begin{array}{c}\text { Risk } \\
\text { Control }\end{array}$ & $\begin{array}{l}\text { HIRARCY of } \\
\text { Control }\end{array}$ \\
\hline 1 & $\begin{array}{l}\text { Galian tanah } \\
\text { /Timbunan dengan } \\
\text { Excavator }\end{array}$ & $\begin{array}{l}\text { Pekerja atau } \\
\text { alat berat jatuh } \\
\text { kedalam galian }\end{array}$ & 7 & High & $\begin{array}{l}\text { SOP } \\
\text { Pengali } \\
\text { an tahah } \\
\text { yang baik } \\
\text { dan benar }\end{array}$ & Administratif \\
\hline 2 & Aktifitas pemotongan & $\begin{array}{l}\text { Mata terkena } \\
\text { percikan api } \\
\text { dan asap }\end{array}$ & 10,17 & $\begin{array}{l}\text { Exstri } \\
\text { m }\end{array}$ & $\begin{array}{l}\text { Memodifik } \\
\text { asi APD } \\
\text { yang telah } \\
\text { di gunakan } \\
\text { tetapi tetap } \\
\text { sesuai } \\
\text { dengan } \\
\text { SOP yang }\end{array}$ & $\begin{array}{l}\text { Rekayasa } \\
\text { Engineering }\end{array}$ \\
\hline
\end{tabular}




\begin{tabular}{|c|c|c|c|c|c|c|}
\hline & & & & & berlaku & \\
\hline 3 & $\begin{array}{l}\text { Pekerjaan pondasi } \\
\text { bore pile }\end{array}$ & $\begin{array}{l}\text { Tertimpa bore } \\
\text { pile }\end{array}$ & 15,33 & $\begin{array}{c}\text { Exstri } \\
\mathrm{m}\end{array}$ & $\begin{array}{l}\text { SOP cara } \\
\text { mengerja } \\
\text { kan } \\
\text { pondasi } \\
\text { bore pile } \\
\text { yang baik } \\
\text { dan benar }\end{array}$ & Administratif \\
\hline 4 & $\begin{array}{l}\text { Galian/timbunan } \\
\text { dengan mengguanakan } \\
\text { alat berat }\end{array}$ & $\begin{array}{l}\text { Alat berat } \\
\text { menbrak } \\
\text { fasilitas sekitar }\end{array}$ & 7,67 & High & $\begin{array}{l}\text { SOP } \\
\text { Penggali } \\
\text { an tahah } \\
\text { yang baik } \\
\text { dan benar }\end{array}$ & Administratif \\
\hline 5 & Galian Manual & $\begin{array}{l}\text { Tertimpa } \\
\text { material jatuh } \\
\text { ketika di angkat }\end{array}$ & 6,25 & High & $\begin{array}{l}\text { Mengguna } \\
\text { kan APD } \\
\text { sesuai } \\
\text { dengan } \\
\text { SOP yang } \\
\text { berlaku }\end{array}$ & $\begin{array}{l}\text { Alat } \\
\text { Perlindungan } \\
\text { Diri (APD) }\end{array}$ \\
\hline 6 & Pekerjaan Scafolding & $\begin{array}{l}\text { Tagan atau kaki } \\
\text { bisa terkilir } \\
\text { atau patah }\end{array}$ & 13,50 & $\begin{array}{c}\text { Exstri } \\
\mathrm{m}\end{array}$ & $\begin{array}{l}\text { Mengguna } \\
\text { kan APD } \\
\text { sesuai } \\
\text { dengan } \\
\text { SOP yang } \\
\text { berlaku }\end{array}$ & $\begin{array}{l}\text { Alat } \\
\text { Perlindungan } \\
\text { Diri (APD) }\end{array}$ \\
\hline 7 & $\begin{array}{l}\text { Lifting material } \\
\text { dengan tower crane }\end{array}$ & $\begin{array}{l}\text { Tertimpa } \\
\text { material dari } \\
\text { ketinggian }\end{array}$ & 20,00 & $\begin{array}{c}\text { Exstri } \\
\mathrm{m}\end{array}$ & $\begin{array}{l}\text { SOP cara } \\
\text { pengangkat } \\
\text { an yang } \\
\text { baik dan } \\
\text { benar }\end{array}$ & Administratif \\
\hline 8 & $\begin{array}{l}\text { Pekerjaan pembuatan } \\
\text { bekisting }\end{array}$ & $\begin{array}{l}\text { Tertimpa } \\
\text { material.ketika } \\
\text { di pasangkan }\end{array}$ & 7,50 & High & $\begin{array}{l}\text { SOP } \\
\text { mengerjak } \\
\text { an yang } \\
\text { baik dan } \\
\text { benar }\end{array}$ & Administratif \\
\hline 9 & $\begin{array}{l}\text { Pekerjaan } \\
\text { pembongkaran } \\
\text { Bekisting }\end{array}$ & $\begin{array}{l}\text { Tagan atau kaki } \\
\text { bisa terkilir } \\
\text { atau patah }\end{array}$ & 8,67 & High & $\begin{array}{l}\text { Mengguna } \\
\text { kan APD } \\
\text { sesuai } \\
\text { dengan } \\
\text { SOP yang } \\
\text { berlaku }\end{array}$ & $\begin{array}{l}\text { Alat } \\
\text { Perlindungan } \\
\text { Diri (APD) }\end{array}$ \\
\hline 10 & Pekerjaan pembesian & $\begin{array}{l}\text { Tangan terjepit } \\
\text { ketika } \\
\text { membengkokan } \\
\text { besi }\end{array}$ & 9,42 & $\begin{array}{l}\text { Exstri } \\
\mathrm{m}\end{array}$ & $\begin{array}{l}\text { Mengguna } \\
\text { kan APD } \\
\text { sesuai } \\
\text { dengan } \\
\text { SOP yang } \\
\text { berlaku }\end{array}$ & $\begin{array}{l}\text { Alat } \\
\text { Perlindungan } \\
\text { Diri (APD) }\end{array}$ \\
\hline
\end{tabular}




\begin{tabular}{|c|c|c|c|c|c|c|}
\hline 11 & Pekerjaan pengecoran & $\begin{array}{l}\text { Tertimpa bahan } \\
\text { material. }\end{array}$ & 5,92 & High & $\begin{array}{l}\text { SOP } \\
\text { mengerjak } \\
\text { an yang } \\
\text { baik dan } \\
\text { benar }\end{array}$ & Administratif \\
\hline 12 & $\begin{array}{l}\text { Pemasangan Rangka } \\
\text { atap dan penutu patap }\end{array}$ & $\begin{array}{l}\text { Tagan atau kaki } \\
\text { bisa terkilir } \\
\text { atau patah }\end{array}$ & 14,75 & $\begin{array}{l}\text { Exstri } \\
\mathrm{m}\end{array}$ & $\begin{array}{l}\text { Mengguna } \\
\text { kan APD } \\
\text { sesuai } \\
\text { dengan } \\
\text { SOP yang } \\
\text { berlaku }\end{array}$ & $\begin{array}{l}\text { Alat } \\
\text { Perlindungan } \\
\text { Diri (APD) }\end{array}$ \\
\hline 13 & $\begin{array}{l}\text { Membersihkan dan } \\
\text { merapikan area kerja } \\
\text { setelah proses } \\
\text { pemotongan }\end{array}$ & $\begin{array}{l}\text { Gangguan pada } \\
\text { saluran } \\
\text { pernafasan }\end{array}$ & 5,83 & High & $\begin{array}{l}\text { Mengguna } \\
\text { kan APD } \\
\text { sesuai } \\
\text { dengan } \\
\text { SOP yang } \\
\text { berlaku }\end{array}$ & $\begin{array}{l}\text { Alat } \\
\text { Perlindungan } \\
\text { Diri (APD) }\end{array}$ \\
\hline 14 & $\begin{array}{l}\text { Mengecek kembali } \\
\text { material yang telah di } \\
\text { potong }\end{array}$ & $\begin{array}{l}\text { Tangan } \\
\text { melupuh atau } \\
\text { luka bakar } \\
\text { ringan }\end{array}$ & 7,25 & High & $\begin{array}{l}\text { Mengguna } \\
\text { kan APD } \\
\text { sesuai } \\
\text { dengan } \\
\text { SOP yang } \\
\text { berlaku }\end{array}$ & $\begin{array}{l}\text { Alat } \\
\text { Perlindungan } \\
\text { Diri (APD) }\end{array}$ \\
\hline 15 & $\begin{array}{l}\text { Pemasangan dinding } \\
\text { pelesteran }\end{array}$ & $\begin{array}{l}\text { Gangguan } \\
\text { pernafasan } \\
\text { akibat debu } \\
\text { pasir dan semen }\end{array}$ & 6,58 & High & $\begin{array}{l}\text { Mengguna } \\
\text { kan APD } \\
\text { sesuai } \\
\text { dengan } \\
\text { SOP yang } \\
\text { berlaku }\end{array}$ & $\begin{array}{l}\text { Alat } \\
\text { Perlindungan } \\
\text { Diri (APD) }\end{array}$ \\
\hline 16 & Pemasangan keramik & $\begin{array}{l}\text { Pekerja terluka } \\
\text { akibat terkena } \\
\text { potongan } \\
\text { keramik }\end{array}$ & 8,50 & High & $\begin{array}{l}\text { Mengguna } \\
\text { kan APD } \\
\text { sesuai } \\
\text { dengan } \\
\text { SOP yang } \\
\text { berlaku }\end{array}$ & $\begin{array}{l}\text { Alat } \\
\text { Perlindungan } \\
\text { Diri (APD) }\end{array}$ \\
\hline 17 & Instalasi listrik & $\begin{array}{l}\text { Terdapat } \\
\text { percikan api } \\
\text { menimbulkan } \\
\text { kebakaran }\end{array}$ & 15,58 & $\begin{array}{l}\text { Exstri } \\
\mathrm{m}\end{array}$ & $\begin{array}{l}\text { SOP } \\
\text { mengerjak } \\
\text { an yang } \\
\text { baik dan } \\
\text { benar }\end{array}$ & Administratif \\
\hline
\end{tabular}

\section{PENUTUP}

Dari hasil penelitian yang diperolehpenulis dapat menyimpulkan hasil sebagai berikut :

1) Berdasarkan hasil wawancara dan pengumpulan beberapa dokumen terkait program keselamatan konstruksi kepada beberapa narasumber didapatkan bahwa kontraktor pelaksana tidak menyiapkan dokumen Rencana Keselamatan Konstruksi yang jelas. Penerapan SMKK hanya berdasarkan kepada pertemuan di pagi hari dan pemeriksaan Alat Pelindung Diri
(APD) bagi pekerja sebelum memulai aktivitas proyek, mengingat kondisi ini memerlukan rekomendasi dalam penyusunan dokumen RKK.

2) Hasilpengolahan kuisioner secara keseluruhan menunjukkan nilai $\mathrm{r}$ hitung lebih besar dari nilai tabel (r-tabel), pada taraf signifikan $(\partial)=0,05 \%$ dan $\mathrm{df}=30-2$ $=28$ yang menunjukkan angka $\mathrm{r}$ tabel 0,361 dan dari perbandingan tersebut maka butirbutir pertanyaan dari variabel tahapan perencanaan dinyatakan valid dan dari hasil 
Uji Reliabilitas variabel menggunakan SPSS 2.1dapat disimpulkan bahwa dari 17 (tujuh belas)pertanyaan reliable (handal), dikatakan handal karena hasil pengolahan statistik keseluruhan variabel nilai alpha besar dari >0,6. Berdasarkan hasil-hasil pengujian ini, variabel resiko $\mathrm{KK}$ dapat digunakan untuk penilaian resiko dengan metode HIRARC.

3) Hasil pengolahan data metode HIRARC, dapat disimpulkan berdasarkan penggolongan matriks resiko di peroleh 7 (tujuh)variabel dengan risiko tingkat Extreme(41\%), dan 10 (sepuluh) variabelresiko tingkat tinggi (High) sebanyak 59\%, maka tingkat risko paling paling banyak yaitu resiko tinggi (High).

\section{DAFTAR PUSTAKA}

1. Toding, et al. (2016). Analisis Penerapan Sistem Manajemen Kesehatan Dan Keselamatan Kerja (SMK3) di RSIA Kasih Ibu Manado. Jurnal Ilmiah Farmasi UNSRAT Vol.5 No. 1 Februari 2016 ISSN: 2302-2493.

2. Soputan, G, E, M, et al. (2014). Manajemen Risiko Kesehatan Dan Keselamatan Kerja (K3) (Study Kasus Pada Pembangunan Gedung SMA Eben Haezar).Jurnal Ilmiah Media Egineering Vol.4 No. 4 Desember 2014 (229-238) ISSN: 2087-9334.

3. Ramadhan, F. (2017). Analisis Kesehatan dan Keselamatan Kerja (K3) Menggunakan Metode Hazard Identification Risk Assessment and Risk Control (HIRARC).Seminar Nasional Riset Terapan 2017. ISSN: 978-602-73672-1-0.
4. Wijaya, et al. (2015).Evaluasi Kesehatan dan Keselamatan Kerja dengan Metode HIRARC pada PT. Charoen Pokphand Indonesia. Jurnal Titra, Vol 3, No 1, Januari 2015, pp. 29-34.

5. Kani. (2014). Keselamatan Dan Kesehatan Kerja Pada Pelaksanaan Proyek kontruksi (Studi Kasus: Proyek PT. Trakindo Utama). Jurnal Sipil Statik Vol.1 No. 6 Mei 2013 (430-433) ISSN: 2337-6732.

6. Rusli, et al. (2017). Implementation of The Management System on Safety And Health To Contruction Workers. International journal Of Engineering Invetions volume, 6 Issue 6 June 2017 PP : 35-39 e- ISSN: 2278-7461, p-ISSN: 2319-6491.

7. Santoso, et al. (2016). Analisis Sistem Manajemen Keselamatan Dan Kesehatan Kerja (SMK3) Dengan Pendekatan Faktor Kesalahan Manusia Di PT.Khalifah Niaga Lantabura. Jurnal REKAVASI Vol, 4 No. 1 Mei 2016 37-46 ISSN: 2338-7750.

8. Wiyasa. (2015). Manajemen Risiko Keselamatan Dan Kesehatan Kerja (K3) Pada Proyek Pembangunan Ciputra World Jakarta. Jurnal Spektran Vol.3.No.1.Januari 2015.

9. Modul Bimbingan Teknis Sistem Manajemen Keselamatan Konstruksi Kerjasama antara Balai Jakon Wilayah I Banda Aceh dengan A2K4-I Sumbar. Direktorat Bina Penyelenggaraan Jasa Konstruksi, Direktorat Jenderal Bina KonstruksiKementerian Pekerjaan Umum dan Perumahan Rakyat (2020). 